Acta Protozool. (2017) 56: 221-233

www.ejournals.eu/Acta-Protozoologica

doi:10.4467/16890027AP.17.020.7822

PROTOZOOLOGICA

\title{
Systematic Studies on the Hypotrich Ciliate, Tachysoma pellionellum (Müller, 1773) Borror, 1972 (Protozoa, Ciliophora) Based on Integrative Analyses: Morphology, Morphogenesis and Molecular Phylogeny
}

\author{
Lingyun CHEN ${ }^{1,2}$, Xiaolu ZHAO ${ }^{2}$, Hamed A. EL-SEREHY ${ }^{3}$, Jie HUANG ${ }^{4}$, John C. CLAMP ${ }^{5}$ \\ ${ }^{1}$ College of Life Science, Northwest Normal University, Lanzhou, China; ${ }^{2}$ Institute of Evolution and Marine Biodiversity, Ocean \\ University of China, Qingdao, China; ${ }^{3}$ Department of Zoology, King Saud University, Riyadh, Saudi Arabia; ${ }^{4}$ Key Laboratory of \\ Aquatic Biodiversity and Conservation of Chinese Academy of Sciences, Institute of Hydrobiology, Chinese Academy of Sciences, \\ Wuhan, China; ${ }^{5}$ Department of Biological and Biomedical Sciences, North Carolina Central University, Durham, North Carolina, \\ USA
}

\begin{abstract}
Tachysoma pellionellum Stokes, 1887, a freshwater ciliate isolated from Stone Mountain State Park, North Carolina, was studied in vivo and after staining with protargol. The population was characterized mainly by having the typical 18 frontal-ventral-transverse cirri; posterior ends of left and right marginal rows not confluent; five dorsal kineties and one dorsomarginal kinety; two macronuclear nodules near left cell margin with one or two micronuclei between them; contractile vacuole located at mid-body near left margin. Morphogenesis is characterized as follows: (1) in the proter, the parental adoral zone of membranelles is retained completely; (2) 18 frontal-ventral-transverse cirri are derived from the anlage of the undulating membrane and the five streaks of the frontal-ventral-transverse anlagen; (3) marginal rows develop intrakinetally; (4) anlagen of dorsal kineties 1, 2 and 4 develop in the parental structure and anlagen of dorsal kineties 2 and 4 fragment in the posterior region forming anlagen of dorsal kineties 3 and 5; (5) only one dorsomarginal kinety formed; (6) the two macronuclear nodules fuse into a single mass, which then divides. Phylogenetic analyses based on sequences of the gene coding for SSU RNA revealed a close relationship between T. pellionellum and the Oxytricha clade, both of which grouped with Kleinstyla dorsicirrata and Heterourosomoida lanceolata.
\end{abstract}

Key words: fresh water ciliate, ontogenesis, phylogenetic analysis, taxonomy

\section{INTRODUCTION}

Ciliates in the subclass Hypotrichia Stein, 1859 are abundant in ecosystems worldwide and exhibit both a great biological and morphological diversity (Berg-

Address for correspondence: J. Clamp, Department of Biology, North Carolina Central University, Durham, North Carolina 27707, USA; E-mail: jclamp@NCCU.EDU er 1999, 2006, 2008, 2011; Foissner et al. 2002; Shao et al. 2007; Song et al. 2009; Bharti et al. 2016; Foissner 2016; Chen et al., 2017). Patterns of morphogenesis and analyses of data from gene sequences are widely used in order to determine phylogenetic relationships among ciliates. However, morphogenetic data are still limited for hypotrichs, considering their high diversity (Shao et al. 2013; Li et al. 2013; Bharti et al. 2017; Lu et al. 2017; Kumar and Foissner 2017; Park et al. 
2017a, 2017b). Members of the large hypotrich family Oxytrichidae have broadly similar patterns of morphogenesis, but there are a number of significant differences in detail among them (Kumar et al. 2016; Wang et al. 2016, 2017).

The genus Tachysoma was established by Stokes in 1887, with T. pellionellum as the type species. Subsequently, more species were described and, at present, seven species are assigned to Tachysoma, i.e., T. pellionellum (Müller, 1773) Borror, 1972, T. balatonicum Gellért and Tamás, 1958, T. bicirratum Foissner, Blatterer, Berger and Kohmann, 1991, T. terricolum Hemberger, 1985, T. granuliferum Berger and Foissner, 1987, T. chilense (Bürger, 1905) Berger, 1999, T. humicolum Gellért, 1957. Morphogenesis of Tachysoma has been investigated only for T. pellionellum, which shows a Tachysoma formative pattern of dorsal ciliature, i.e., two dorsal anlagen fragments, dorsomarginal kineties present, and caudal cirri absent, which differs from that seen in all other oxytrichid genera (Berger 1999; Shao et al. 2012, 2015).

The present paper describes the morphology and binary fission of a population of Tachysoma pellionellum collected from a limnetic habitat in the eastern U.S. and analyzes its phylogenetic position based on sequences of the gene coding for SSU rRNA.

\section{MATERIALS AND METHODS}

Sample site and cultivation: Samples were collected on 10th June 2015 from a freshwater pool below Widow's Creek Falls $\left(36^{\circ} 14^{\prime} 07^{\prime \prime} \mathrm{N}, 81^{\circ} 02^{\prime} 27^{\prime \prime} \mathrm{W}\right)$ in Stone Mountain State Park, North Carolina, USA (Fig. 1A-D). The water temperature was $25^{\circ} \mathrm{C}$ and $\mathrm{pH}$ measured 6.5. Clonal cultures were used for studies of Tachysoma pellionellum. These were maintained in Petri dishes at approximately $24^{\circ} \mathrm{C}$, using mineral water with a few wheat grains added to enhance bacterial growth as a medium (Shao et al. 2011).

Morphology, morphogenesis, and voucher material: Live observations were carried out using bright field and Nomarski differential interference contrast microscopy. Staining with protargol (Wilbert 1975) was done to reveal the infraciliature. Counts and measurements of stained specimens were performed at a magnification of 1,000 $\times$. Drawings were made with the help of a camera lucida. In illustrations illustrating changes that occurred during morphogenesis, parental structures are depicted by contour, and new ones are shaded black (Li et al. 2017).

Two voucher slides (protargolpreparations) have been deposited, one in the laboratory of Protozoology, Ocean University of China (registry number: CLY2015061004) and the other in the Natural History Museum, London (registry number: NHMUK 2017.11.27.1).
Terminology and systematics: Terminology is mainly according to Berger $(1999,2008)$, the numbering system established by Wallengren (1900) was used for designation of the frontal-ventraltransverse (FVT) cirri and anlagen (for details see Berger 1999). The term "18-cirri hypotrich" means a hypotrich with 18 FVT cirri (Berger 2008).

DNA extraction, PCR amplification, and sequencing: Genomic DNA was extracted from cells washed with autoclaved fresh water using a DNeasy Blood and Tissue Kit (Qiagen, CA) with the modification that $25 \%$ of the volume suggested for each solution was used (Zhao et al. 2015). The SSU rRNA gene was amplified using the universal primers EukA and EukB (Medlin et al. 1988). Cloning and sequencing were performed as reported by Huang et al. (2016).

Phylogenetic analyses: Phylogenetic analyses included the SSU rRNA sequence of the American population of Tachysoma pellionellum and 72 other sequences downloaded from GenBank (see Fig. 7 for accession numbers except those of the following 13 urostylids: Anteholosticha pseudomonilata HM568416, Heterokeronopsis pulchra JQ083600, Nothoholosticha fasciola FJ377548, Pseudokeronopsis carnae AY881633, Uroleptopsis citrina GU437211, Pseudourostyla cristata GU942569, Hemicycliostyla sphagni FJ361758, Monocoronella carnea FJ775726, Diaxonella trimarginata DQ190950, Urostyla grandis EF535731, Apokeronopsis wrighti EU417963, Thigmokeronopsis stoecki EU220226 and Metaurostylopsis salina EU220229). Sequences were aligned using Clustal W implemented in Bioedit 7.2.5 with default parameters (Hall 1999). Regions that could not be aligned unambiguously were removed and ends were trimmed manually, resulting in a matrix of 1,755 characters. Four species of the subclasses Oligotrichia and Choreotrichia were chosen as the outgroup taxa. Bayesian inference (BI) analysis was performed with MrBayes 3.2.6 (Ronquist and Huelsenbeck 2003) on the CIPRES Science Gateway using GTR $+\mathrm{I}+\mathrm{G}$ (Shape $=0.4337$, Pinvar $=0.5440)$ as the best model selected by MrModeltest v.2.2 (Nylander 2004) under the Akaike Information Criterion. Four MCMC simulations were run for 1,000,000 generations with a sampling frequency of every 100 generations and a burn-in of 2500 trees $(25 \%)$. Maximum-likelihood (ML) trees were constructed on the CIPRES Science Gateway using RAxML-HPC2 on XSEDE (8.2.4) with 1000 bootstrap replicates. TREEVIEW v1.6.6 (Page 1996) and MEGA 6.05 (Tamura et al. 2007) were used to visualize tree topologies.

\section{RESULTS}

\section{Morphology of American population of Tachysoma pellionellum (Figs 2 and 3; Table 1)}

Body measuring 70-90 $\mu \mathrm{m} \times 25-40 \mu \mathrm{m}$ in vivo, length/width approximately $3: 1$ in vivo, $2.2: 1$ on average in fixed and stained cells. Flexible and non-contractile, usually slender oval to elliptical with anterior end slightly narrowed, posterior broadly rounded; left margin slightly convex, right margin convex in typical individuals (Figs 2A, 3A). Dorsoventrally flattened 


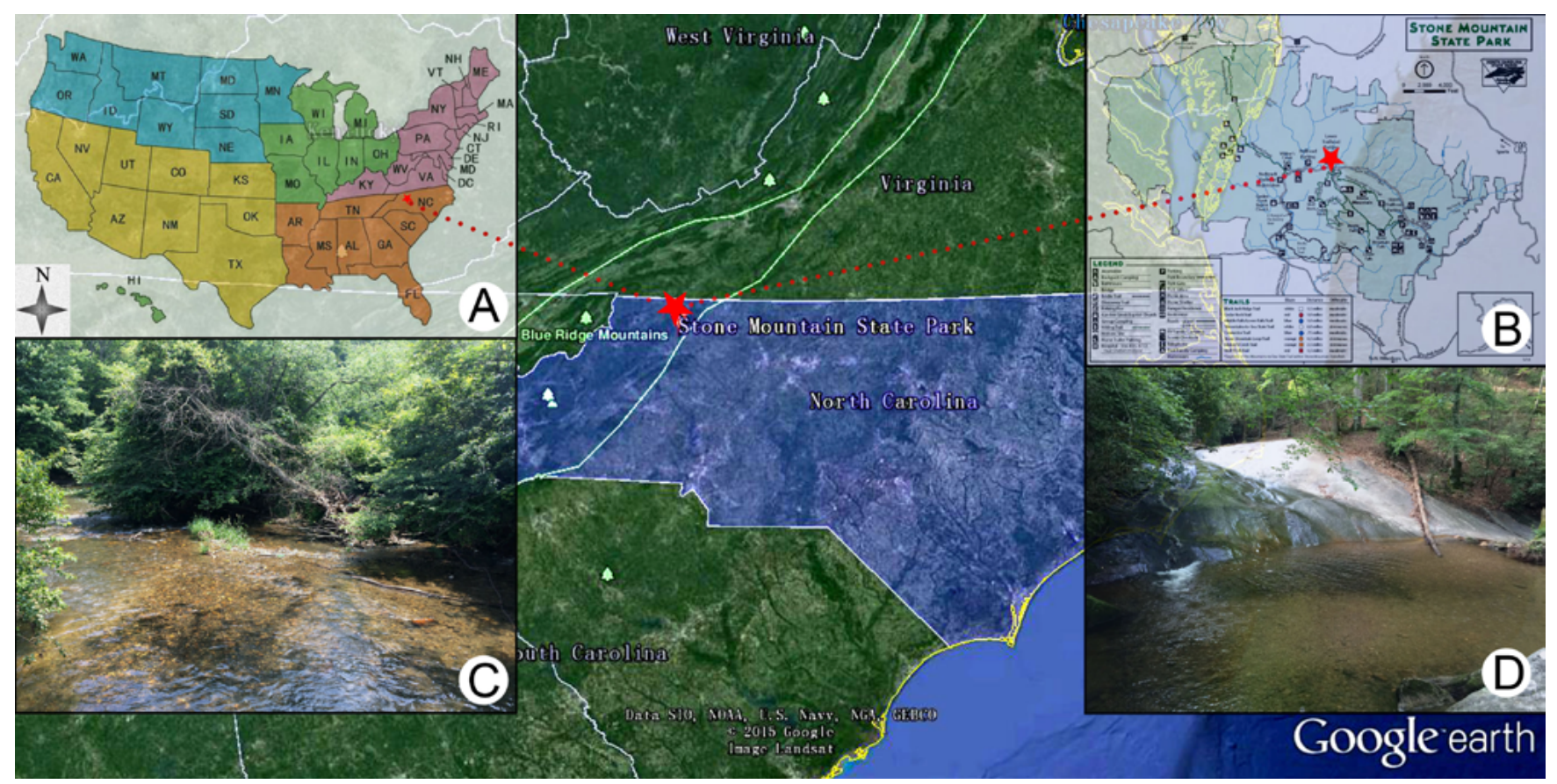

Fig. 1. Map of North America (the background from Google earth) showing the sampling sites. (A, B) Map showing Stone Mountain State Park, North Carolina, USA. (C, D), where Tachysoma pellionellum was collected.

(ca. 2.5 : 1); ventral side flat, dorsal side slightly convex in middle portion. Cells colorless to grey; cytoplasm colouless, containing several food vacuoles filled with bacteria, refringent cytoplasmic crystals, and granules measuring 1-4 $\mu \mathrm{m}$ in diameter (Figs 2B, C, 3B-D). Usually a very conspicuous, $\sim 10 \mu \mathrm{m}$, refringent globule that resembles a ring with a thick (ca. $1 \mu \mathrm{m})$ wall in both ends of cell (Figs 2C, 3C, D). Cortical granules absent. Contractile vacuole measuring approximately $10 \mu \mathrm{m}$ in diameter during diastole, located approximately in midbody region near left margin (Figs 2A-C, 3B, C). Two ellipsoidal macronuclear nodules, measuring approximately $24 \mu \mathrm{m} \times 12 \mu \mathrm{m}$ in vivo, usually arranged in a linear series left of midline in the central body portion, with small to moderately large nucleoli (Figs 2A, 3A). One spherical micronucleus between the two closely spaced macronuclear nodules (Fig. 2F). Locomotion by slow crawling on substrate or by swimming while rotating about longitudinal axis of body.

Infraciliature as shown in Figs 2D-F, 3E-H. Adoral zone occupies $30-35 \%$ of cell length in vivo (ca. $30 \%$ after fixation and staining); composed of 20-22 membranelles. Bases of largest adoral membranelles approximately $10 \mu \mathrm{m}$ wide, cilia up to $12 \mu \mathrm{m}$ long (Figs 2D, 3E). Distal portion of adoral zone extends slightly posteriorly onto right side of cell, that is, DE-value about 0.20 (Fig. 2D; for explanation of DE-value, see Berger 2006: 18). Paroral and endoral almost equal in length and parallel to each other, the former slightly longer than the latter (Figs 2D, E, 3E, F). Frontoventral transverse ciliature comprising 18 cirri: three slightly enlarged frontal cirri with cilia about $15 \mu \mathrm{m}$ long; single buccal cirrus near anterior ends of paroral and endoral; frontoventral cirri arranged in a short, mixed, asymmetric, V-shaped row; cirrus III/2 in the level between cirri IV/3 and VI/3; three postoral ventral cirri located medially below vertex and distinctly separated from two pretransverse ventral cirri; five transverse cirri with cilia $15-20 \mu \mathrm{m}$ long and arranged in a roughly hookshaped pseudo-row in posterior region of cell and the rightmost transverse cirrus close to the right marginal row. One right and one left marginal row, posterior ends of which are separated; each row with 13-15 cirri; cilia of marginal cirri about $10 \mu \mathrm{m}$ long (Figs $2 \mathrm{E}, 3 \mathrm{E}-\mathrm{G}$ ).

Six dorsal kineties; dorsal kineties 1, 2 and 5 almost bipolar, comprising 14-19, 10-15, and 11-14 pairs of basal bodies, respectively; dorsal kinety 3 comprising 8-14 pairs of basal bodies, commences at level near $1 / 3$ of body length and extending to posterior end; dorsal kinety 4 comprising $6-8$ pairs of basal bodies, starting 
Table 1. Morphological characterization of Tachysoma pellionellum ${ }^{\mathrm{a}}$

\begin{tabular}{|c|c|c|c|c|c|c|c|}
\hline Characters & Min & Max & Mean & M & SD & $\mathrm{CV}$ & $\mathrm{n}$ \\
\hline Length of body & 64 & 88 & 76.1 & 77.0 & 5.6 & 7.4 & 15 \\
\hline Width of body & 28 & 40 & 31.6 & 31.0 & 3.6 & 11.5 & 15 \\
\hline Length of adoral zone & 21 & 25 & 23.2 & 23.0 & 1.3 & 5.7 & 15 \\
\hline $\begin{array}{l}\text { AE to distal end } \\
\text { of the AZM }\end{array}$ & 5.2 & 7.6 & 5.9 & 5.7 & 0.7 & 11.7 & 15 \\
\hline DE-value ${ }^{b}$ & 0.22 & 0.33 & 0.26 & 0.24 & 0 & 12.0 & 15 \\
\hline Number of adoral membranelles & 20 & 22 & 20.7 & 21.0 & 0.8 & 3.9 & 15 \\
\hline Number of frontal cirri & 3 & 3 & 3.0 & 3.0 & 0 & 0 & 15 \\
\hline Number of buccal cirri & 1 & 1 & 1.0 & 1.0 & 0 & 0 & 15 \\
\hline Number of frontoventral cirri & 4 & 4 & 4.0 & 4.0 & 0 & 0 & 15 \\
\hline Number of postoral ventral cirri & 3 & 3 & 3.0 & 3.0 & 0 & 0 & 15 \\
\hline Number of pretransverse cirri & 2 & 2 & 2.0 & 2.0 & 0 & 0 & 15 \\
\hline Number of transverse cirri & 5 & 5 & 5.0 & 5.0 & 0 & 0 & 15 \\
\hline Number of left marginal cirri & 13 & 15 & 13.9 & 14.0 & 0.6 & 4.3 & 15 \\
\hline Number of right marginal cirri & 13 & 15 & 13.9 & 14.0 & 0.5 & 3.3 & 15 \\
\hline Number of dorsal kineties & 6 & 6 & 6.0 & 6.0 & 0 & 0 & 15 \\
\hline Number of basal bodies in dorsal kinety 1 & 14 & 19 & 16.3 & 17.0 & 1.5 & 9.1 & 15 \\
\hline Number of basal bodies in dorsal kinety 2 & 10 & 15 & 12.9 & 13.0 & 1.9 & 15.0 & 15 \\
\hline Number of basal bodies in dorsal kinety 3 & 8 & 14 & 9.9 & 10.0 & 1.7 & 16.8 & 15 \\
\hline Number of basal bodies in dorsal kinety 4 & 6 & 8 & 7.1 & 7.0 & 0.5 & 7.5 & 14 \\
\hline Number of basal bodies in dorsal kinety 5 & 11 & 14 & 12.5 & 12.0 & 1.1 & 8.5 & 15 \\
\hline Number of basal bodies in dorsal kinety 6 & 5 & 9 & 5.5 & 5.0 & 1.1 & 19.4 & 15 \\
\hline Number of macronuclear nodules & 2 & 2 & 2.0 & 2.0 & 0 & 0 & 15 \\
\hline Number of micronuclei & 1 & 2 & 1.3 & 1.0 & 0.5 & 36.6 & 15 \\
\hline
\end{tabular}

${ }^{a}$ All data are based on protargol-stained specimens. All measurements in $\mu \mathrm{m}$.

${ }^{\mathrm{b}}$ Indicates the distance between anterior body end and distal end of AZM divided by length of AZM (Berger 2006).

Abbreviations: AE, anterior end of cell; AZM, adoral zone of membranelles; CV, coefficient of variation in \%; M, median; Max, maximum; Mean, arithmetic mean; Min, minimum; $n$, number; SD, standard deviation.

at approximately the anterior end of cell and terminating at point $2 / 3$ of body length toward posterior; dorsal kinety 6 (dorsomarginal kinety) composed of 5-9 dikinetids and begins at anterior end of cell (Figs 2F, 3H).

\section{Morphogenesis during binary fission (Figs 4-6)}

\section{Stomatogenesis}

Opisthe: Division commences with the apokinetal proliferation of groups of closely spaced basal bodies between the left marginal row and the posterior-most postoral ventral cirrus (Figs 4A, B, 6A). Following the proliferation of basal bodies, the oral primordium develops and differentiates new membranelles posteriad (Figs 4C, D, 6B). Then, the anlage of the undulating membranes (UM-anlage) forms to the right of the oral primordium as a long streak of basal bodies (Figs 4E, 6C). Later, the anterior end of the newly organized adoral zone of membranelles (AZM) bends to the right and the differentiation of membranelles is completed, forming the new oral structure for the opisthe. The leftmost frontal cirrus is derived from the anterior end of the UM-anlage (Figs 4G, 5A, C, 6D, E). Subsequently, the UM-anlage splits longitudinally into two streaks from which the endoral and paroral form. Initially, these streaks are closely parallel, but later, they separate and $\operatorname{arch}$ (Figs 5C, E, G, 6G, H).

Proter: The parental AZM is retained intact during morphogenesis, and changes to the oral structure are confined to the paroral and endoral. The first sign of the formation of the UM-anlage is the dedifferentiation 


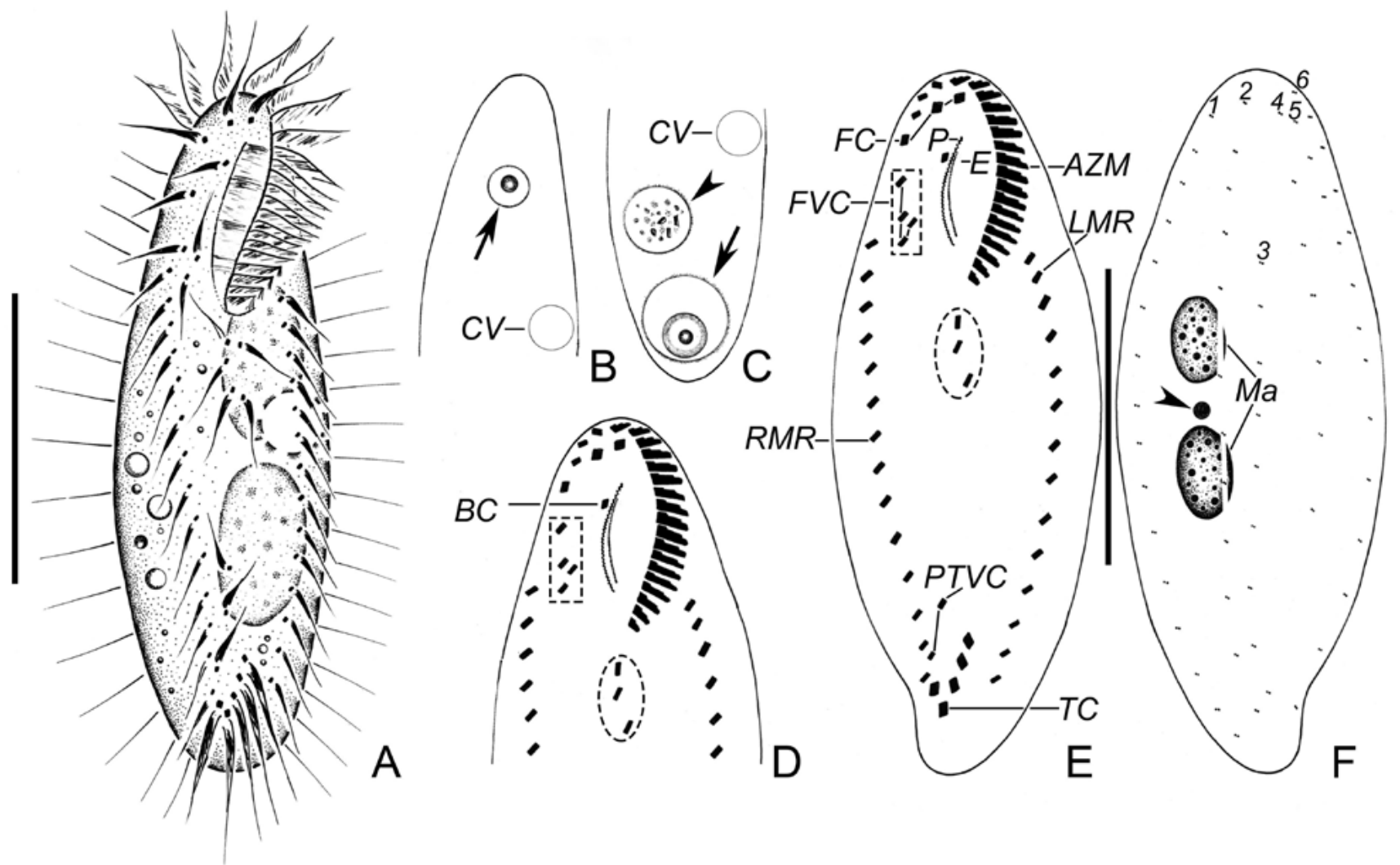

Fig. 2. Morphology of Tachysoma pellionellum from life (A-C) and after protargol staining (D-F). (A) Ventral view of a representative individual. (B, C) Detail of cell, arrows indicate the refringent globules and arrowhead shows the food vacuole. (D) Detailed ventral view of the anterior region, showing the frontoventral (in rectangle) and postoral ventral cirri (in ellipse). (E, F) Ciliature of ventral and dorsal side and nuclear apparatus, the dashed ellipse depicts the postoral ventral cirri; arrowhead indicates the micronucleus. AZM, adoral zone of membranelles; $\mathrm{BC}$, buccal cirrus; $\mathrm{CV}$, contractile vacuole; E, endoral; FC, frontal cirri; FVC, frontoventral cirri; LMR, left marginal row; Ma, macronuclear nodules; P, paroral; PTVC, pretransverse ventral cirri; RMR, right marginal row; TC, transverse cirri; 1-6, dorsal kineties. Scale bars: $40 \mu \mathrm{m}$.

of the anterior portion of the old paroral (Figs 4E, 6C). Later, basal bodies proliferate in both paroral and endoral giving rise to the UM-anlage (Figs 4G, 6D). In subsequent stages, the basic development of the UManlage follows a similar pattern to that in the opisthe.

Development of the anlagen of the frontal-ventraltransverse cirri: Development of the somatic ciliature begins with the formation of the anlagen of the frontalventral-transverse cirri. Frontoventral and undulating membranes remain intact (Figs 4A, B, 6A). For lack of some stages, we were not able to identify whether the postoral ventral cirri will contribute to the formation of the streaks. Probably, at least some postoral ventral cirri will contribute to the FVT anlagen (Figs. 4A, B). Later, streaks II-VI form as the first indication of the five frontal-ventral-transverse cirri (Figs 4C, D, 6B). They appear initially as a single set (primary pattern) that subsequently divides into two groups (Figs 4E, G, 6C, D). As mentioned above, the leftmost frontal cirrus is formed from the UM-anlage in each dividing part (Figs $4 \mathrm{G}, 5 \mathrm{~A}, \mathrm{C}, 6 \mathrm{D}, \mathrm{E}, \mathrm{G})$. After segregation and migration of the cirri that develop from the six anlagen (including UM-anlage), a total of 18 cirri has formed, namely, three frontal, one buccal, four frontoventral, three postoral ventral, two pretransverse ventral and five transverse (Figs 5A, C, E, G, 6E, G, H).

Marginal cirri: Anlagen of the marginal row develop intrakinetally during the mid-stages of division by dedifferentiation of the parental structures. The anlagen of the left marginal row appear somewhat later than those of the right marginal row (Figs 4E, 6C) and then lengthen toward both ends of the dividing cell (Figs $4 \mathrm{G}$, $5 \mathrm{~A}, \mathrm{C}, 6 \mathrm{D}, \mathrm{E}, \mathrm{G})$. Finally, all anlagen of the marginal row generate new cirri that replace the parental ones. 

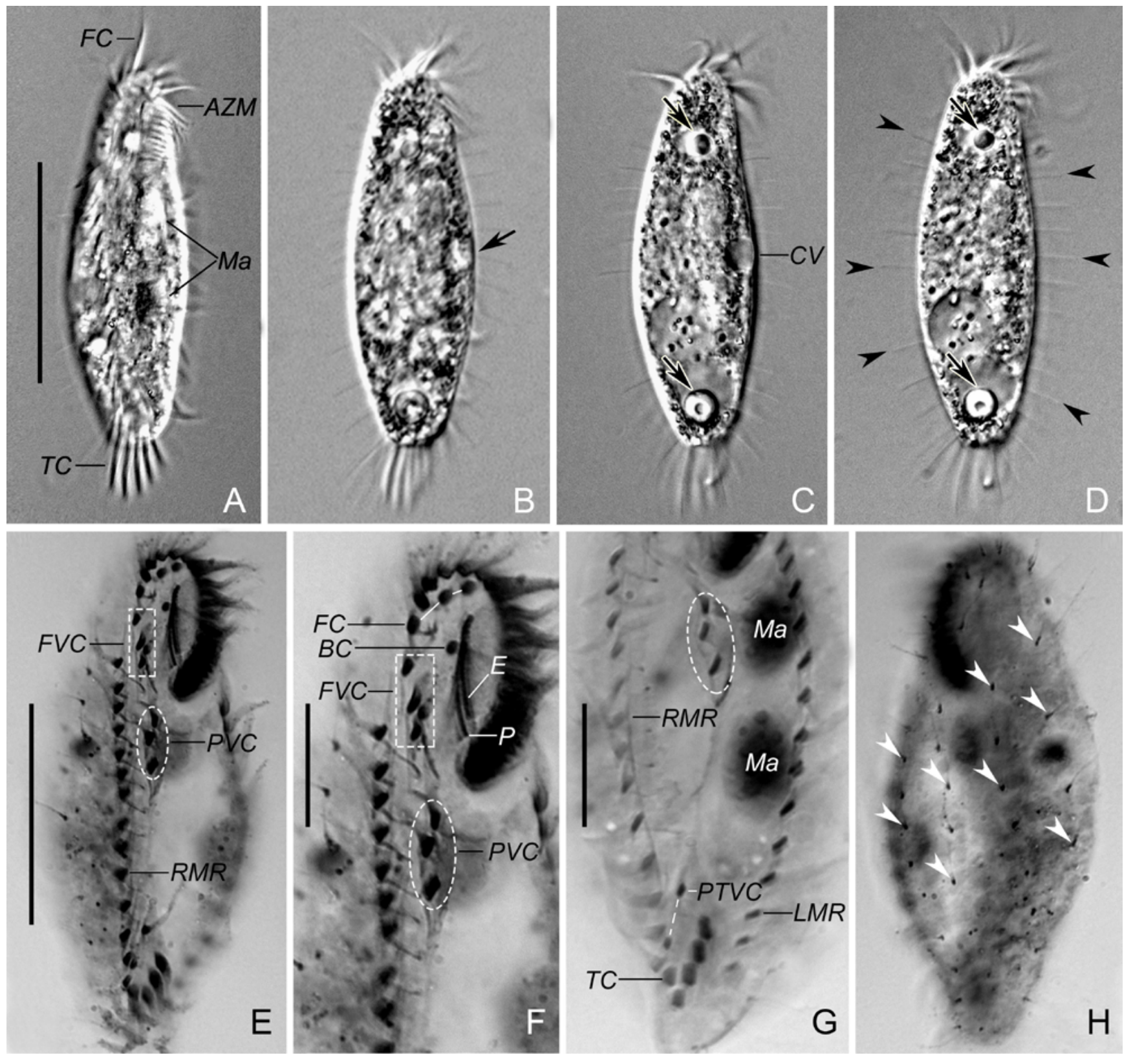

Fig. 3. Photomicrographs of Tachysoma pellionellum in vivo (A-D) and after protargol staining (E-H). (A-D) Ventral views of typical individuals; arrow in Fig. B marks the contractile vacuole, arrows in Fig. C show the refringent globules and arrowheads demonstrate the dorsal cilia. (E) Ventral view of the infraciliature; showing the frontoventral (in rectangle) and postoral ventral cirri (in circle). (F) Ventral view of anterior portion of infraciliature. (G) Ventral view of posterior portion of infraciliature, showing the pretransverse ventral cirri (dashed line). (H) Dorsal view of the infraciliature, showing the dorsal kineties (arrowheads). AZM, adoral zone of membranelles; BC, buccal cirrus; CV, contractile vacuole; E, endoral; FC, frontal cirri; FVC, frontoventral cirri; LMR, left marginal row; Ma, macronuclear nodules; P, paroral; PVC, postoral ventral cirri; PTVC, pretransverse ventral cirri; RMR, right marginal row; TC, transverse cirri; Scale bars: $55 \mu \mathrm{m}(\mathrm{A}), 35 \mu \mathrm{m}(\mathrm{E})$ and $15 \mu \mathrm{m}(\mathrm{F}, \mathrm{G})$.

Dorsal ciliature: Two sets of anlagen of dorsal kineties develop intrakinetally within dorsal kineties 1,2 and 4 in both proter and opisthe (Fig. 4E-H). The an- lagen then elongate mainly posteriad and gradually replace the parental rows (Figs 5A-D, 6G). In late stages of division, anlagen of dorsal kineties 2 and 4 fragment 

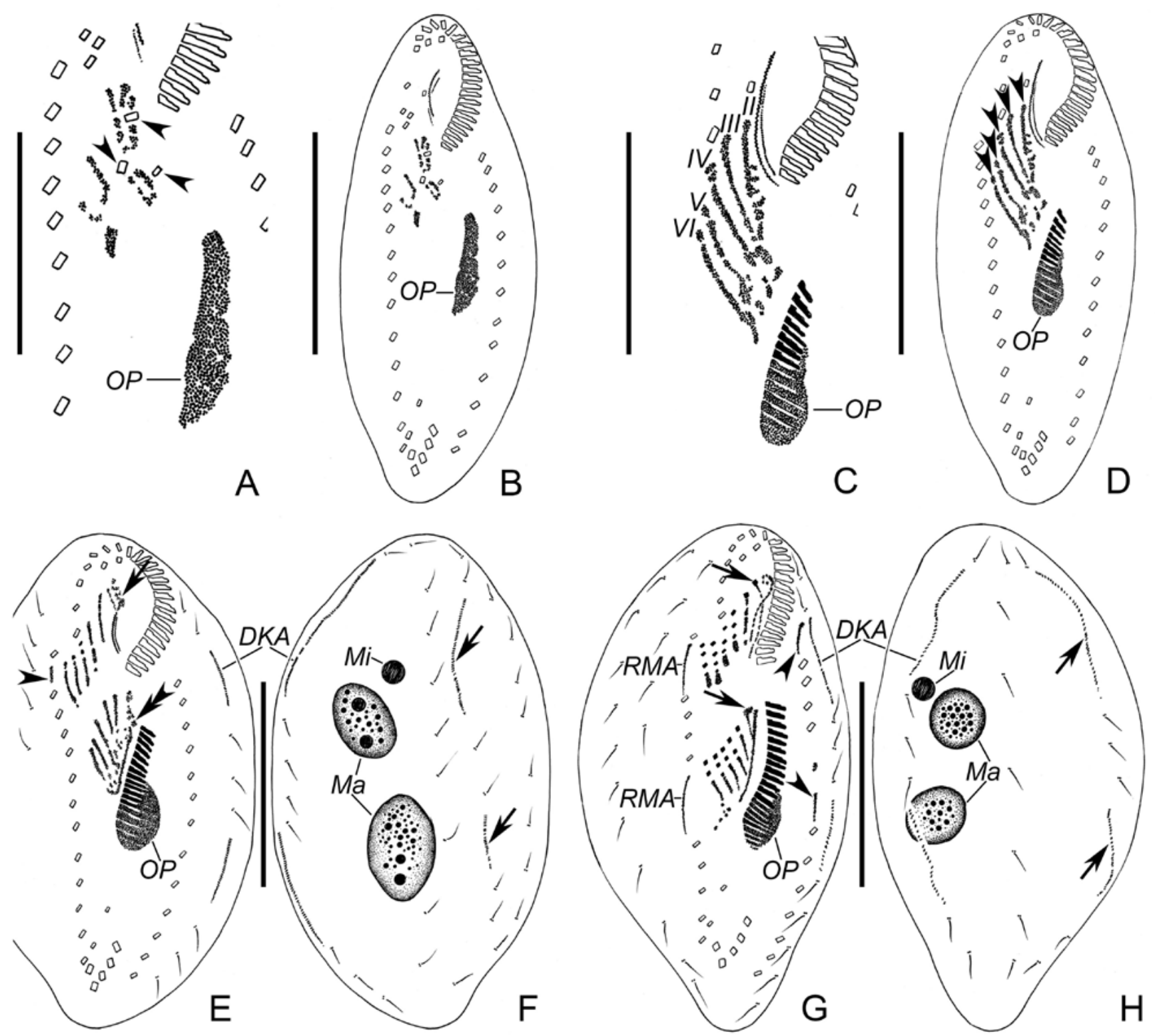

Fig. 4. Divisional morphogenesis in Tachysoma pellionellum (after protargol staining). (A, B) Ventral views of an early divider. Note the basal bodies in the oral primordium forming an elongated field; arrowheads show the postoral ventral cirri which remain intact only for a short time. (C, D) Ventral views of an early divider. Arrowheads show the developing FVT-anlagen. (E, F) Ventral and dorsal view of a divider in early divisional stage. In E, arrow marks the old paroral which is dedifferentiating, double-arrowheads shows the UM-anlage formed to the right of the oral primordium as a long streak of basal bodies and arrowhead indicates the right marginal row anlagen developing intrakinetally; in F, arrows show the intrakinetal formation of the dorsal kineties anlagen 4 in the dividing cell. (G, $\mathbf{H})$ Ventral and dorsal view of a divider in early divisional stage. In $\mathrm{G}$, arrows show the first frontal cirri separating from the undulating membranes anlagen; arrowheads mark the left marginal row anlagen developing intrakinetally; in $\mathrm{H}$, arrows show the intrakinetal formation of the dorsal kineties anlagen 4 in the dividing cell. DKA, dorsal kineties anlagen; II-VI, frontoventral-transverse cirral anlagen; Ma, macronuclear nodules; Mi, micronucleus; OP, oral primordium; RMA, right marginal anlage. Scale bars: $15 \mu \mathrm{m}(\mathrm{A}, \mathrm{C})$ and $35 \mu \mathrm{m}(\mathrm{B}, \mathrm{D}, \mathrm{E}-\mathrm{H})$.

in the posterior region forming dorsal kineties anlagen 3 and 5, respectively. Overall, five anlagen of dorsal kineties form in each daughter cell. Simultaneously, a streak of basal bodies develops to the right of the right marginal row and becomes the dorsomarginal kinety in each daughter cell (Figs 5E-H, 6I). No caudal cirri are formed during morphogenesis (Fig. 5F, H). 

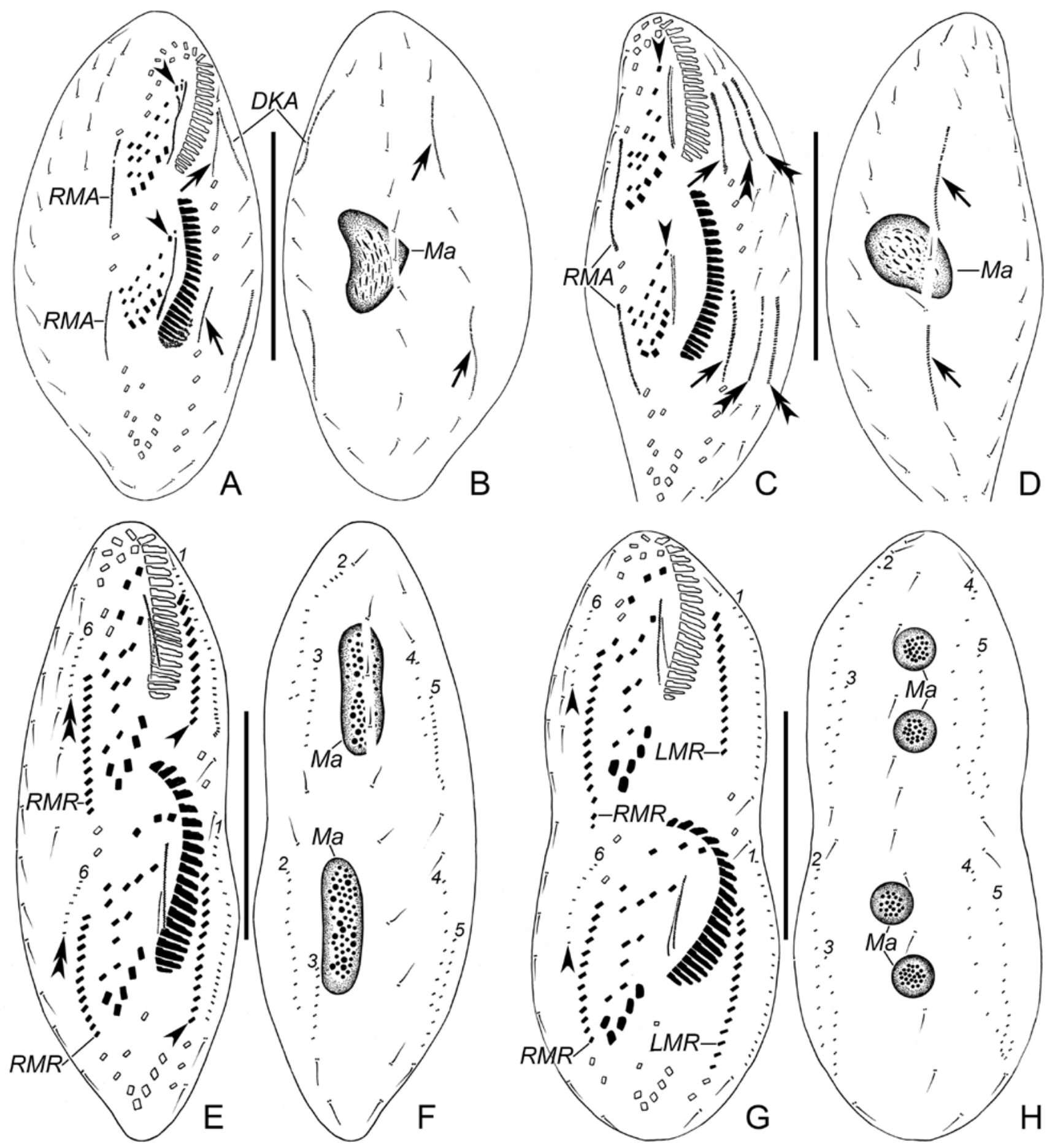

Fig. 5. Middle and late dividers of Tachysoma pellionellum, after protargol staining. (A, B) Ventral and dorsal view of a middle-stage divider. In A, arrowheads show the first frontal cirri and arrows mark the left marginal anlagen; in B, arrows mark the intrakinetal formation of the dorsal kineties anlagen 4. (C, D) Ventral and dorsal view of a mid-divider. In C, arrowheads show the first frontal cirri, arrows mark the left marginal anlagen and double-arrowheads show the anlagen of dorsal kineties; in D, arrows mark the intrakinetal formation of the dorsal kinety anlagen 4. (E, F) Ventral and dorsal view of a late divider; double-arrowheads show the dorsomarginal kineties (dorsal kineties 6) and arrowheads show the left marginal row. (G, H) Ventral and dorsal view of a late-stage divider; arrowheads show the dorsomarginal kineties (dorsal kineties 6). DKA, dorsal kineties anlagen; LMR, left marginal row; Ma, macronuclear nodules; RMA, right marginal anlage; RMR, right marginal row; 1-6, dorsal kineties. Scale bars: $45 \mu \mathrm{m}$. 

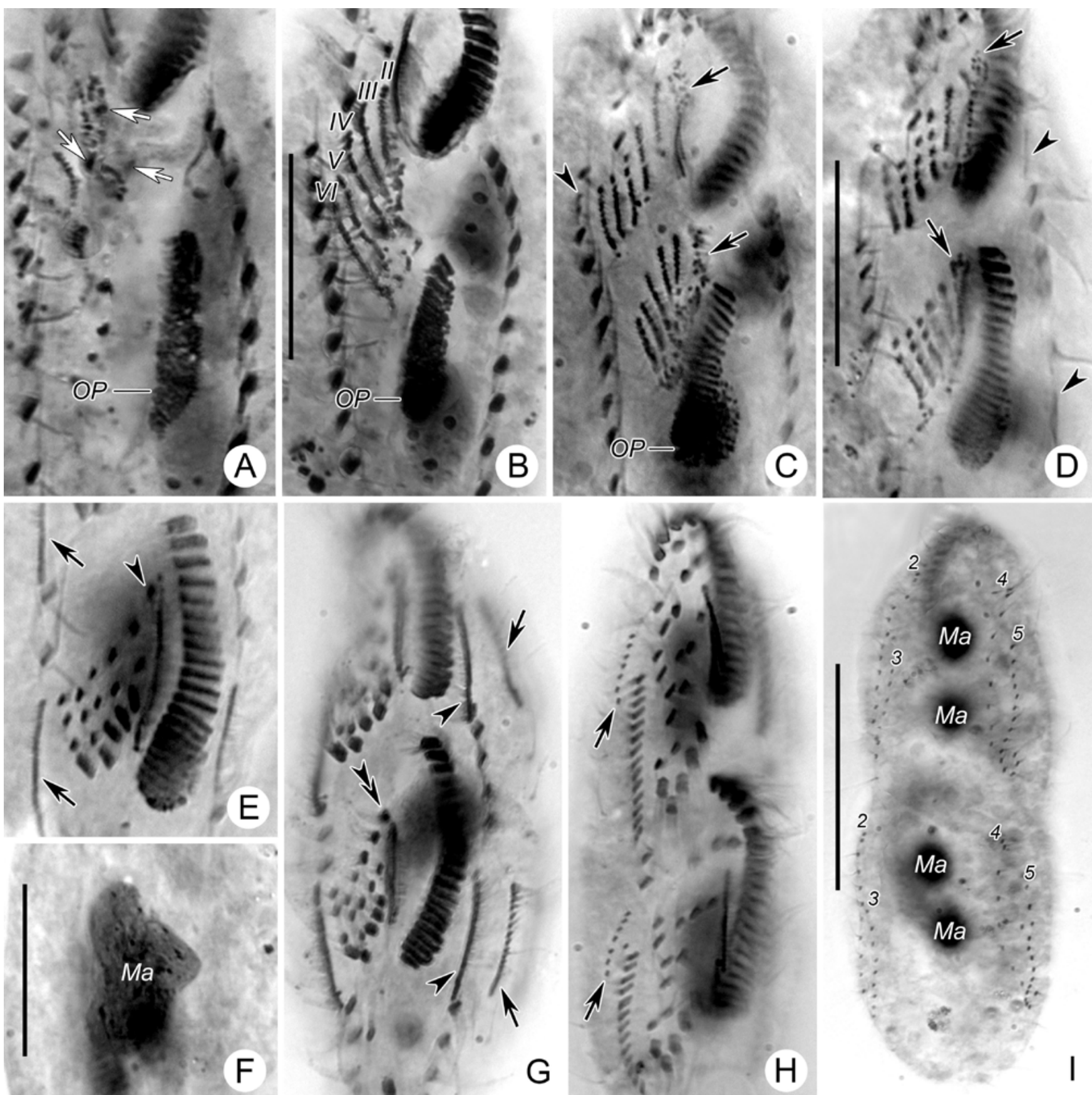

Fig. 6. Photomicrographs of Tachysoma pellionellum during divisional morphogenesis (after protargol staining). (A, B) Ventral views of early dividers, note the basal bodies in the oral primordia forming an elongated field; arrows show the postoral ventral cirri which remain intact. (C, D) Ventral views of early dividers. In C, arrow in the proter marks the paroral which is dedifferentiating; arrow in the opisthe shows the anlage of the undulating membranes, and arrowhead indicates the right marginal anlage; in $\mathrm{D}$, arrows show the first frontal cirri separating from the anlagen of the undulating membranes, and arrowheads mark the left marginal anlagen. (E-G) Ventral and dorsal view of a middle-stage divider. In E, arrowhead shows the first frontal cirrus and arrows mark the right marginal anlagen; in G, double-arrowheads show the first frontal cirrius, arrowheads mark the left marginal anlagen, and arrows show the intrakinetal formation of the dorsal kineties anlagen 1. (H, I) Ventral and dorsal view of a late divider; arrows show the dorsal kineties 6. II-VI, FVT-anlagen; Ma, macronuclear nodules; OP, oral primordium; 2-5, dorsal kineties. Scale bars: $20 \mu \mathrm{m}(\mathrm{B}, \mathrm{D}, \mathrm{F})$ and $45 \mu \mathrm{m}(\mathrm{I})$. 
Division of the nuclear apparatus: The nuclear apparatus divides in the usual way for oxytrichids and hence needs no detailed description. Briefly, two macronuclear nodules fuse to form a single mass during the middle stages of division, which then divides twice prior to cytokinesis (Figs 4F, H, 5B, D, F, H, 6F, I).

\section{Phylogenetic analyses based on SSU rRNA sequenc- es (Fig. 7)}

The SSU rRNA sequence of Tachysoma pellionellum was deposited in the GenBank database with the accession number KX509970. The sequence was 1772 bp long and had a $\mathrm{G}+\mathrm{C}$ content of $46.95 \%$. We included a broad selection of 73 species in the present phylogenetic analyses, including all available SSU rRNA sequences from both the Oxytrichines and Stylonychines. The topologies of the ML and BI trees were basically congruent, and therefore we present only the ML tree with support values from both algorithms indicated on branches (Fig. 7). The American population of Tachysoma pellionellum clusters with the Chinese (Qingdao) population with maximum support (100\% ML, $1.00 \mathrm{BI})$.

\section{DISCUSSION}

\section{Identification of the American population of Tachy- soma pellionellum}

Tachysoma pellionellum was originally discovered by Müller (1773) in an infusion of plant material. Subsequently, it was redescribed by a series of researchers (for revision, see Berger 1999). The American population of $T$. pellionellum corresponds closely with the original and subsequent descriptions (Berger 1999).

It is also noteworthy to point out that two synonymized species (Tachysoma agile, Tachysoma mirabile), were discovered by Stokes (1887) in the eastern United States. No specific localities were given, but specimens probably were collected in the vicinity of Trenton, NJ, where Stokes lived. This is only approximately $700 \mathrm{~km}$ from the locality at which the population described in the present paper was collected and, presumably were coastal-plain habitats rather than the montane stream in which our population was discovered. Stokes's (1887) descriptions documented only the characters of living cells and closely resemble those in our population; therefore, we think that these two species are subjective junior synonyms of Tachysoma pellionellum.
With respect to morphology, the Chinese population investigated by Tchang et al. (1984) has fewer adoral membranelles (20-22 vs. $\sim 40)$, dorsomarginal rows (one vs. two) and cirri in the left (13-15 vs. 34-36) and right (13-15 vs. 36-39) marginal rows than the population described in the present paper. Furthermore, the position and length of dorsal kineties 3-6 are different in both populations. Therefore, we hypothesize that the Chinese population was misidentified, as already stated by Berger (1999: 437).

\section{Morphogenetic comparison with related taxa}

In the present study, we provided supplementary information on morphogenesis in T. pellionellum, which is the type species of Tachysoma. Hemberger (1982) reported the morphogenetic process of a European population of T. pellionellum, which is basically similar to the U.S. population we observed. The only difference of note was in the dorsal pattern, in which the anlage of dorsal kinety 4 develops in the parental dorsal kinety 3 in Hemberger's description but developed in the parental dorsal kinety 4 in our observations. Unfortunately Hemberger didn't illustrate dorsal morphogenesis; therefore we hypothesize that Hemberger (1982) may have omitted the real parental kinety 3 .

The development of the ventral ciliature and nuclear apparatus in the Chinese population described by Tchang et al. (1984) is similar to that in the U.S. population; however, there are several differences in morphogenesis between the two, especially with respect to the formation of the dorsal ciliature. First, the anlagen of the dorsal kineties develop in parental kineties 1-3 in the Chinese population (vs. in kineties 1, 2, 4 in the U.S. population). Also, only the anlage of dorsal kinety 3 fragments in the Chinese population vs. both the dorsal kineties anlagen 2 and 4 in the U.S. population, and two dorsomarginal kineties form in the Chinese population vs. only one dorsomarginal kinety in the U.S. population. Thus, it is no doubt to confirm Chinese population was misidentified.

\section{Phylogenetic position of Tachysoma}

As in previous analyses (Berger 2006: 34; 2008: 47; Schmidt et al. 2007; Gao et al. 2016; Luo et al. 2017), the present study showed that the subfamily Oxytrichinae is not monophyletic, with low support values. The two populations of $T$. pellionellum (morphological details of the Qingdao population KM222096 was described in the doctoral dissertation of Dr. Jiamei Jiang) grouped together with full support, but the phylogenetic posi- 


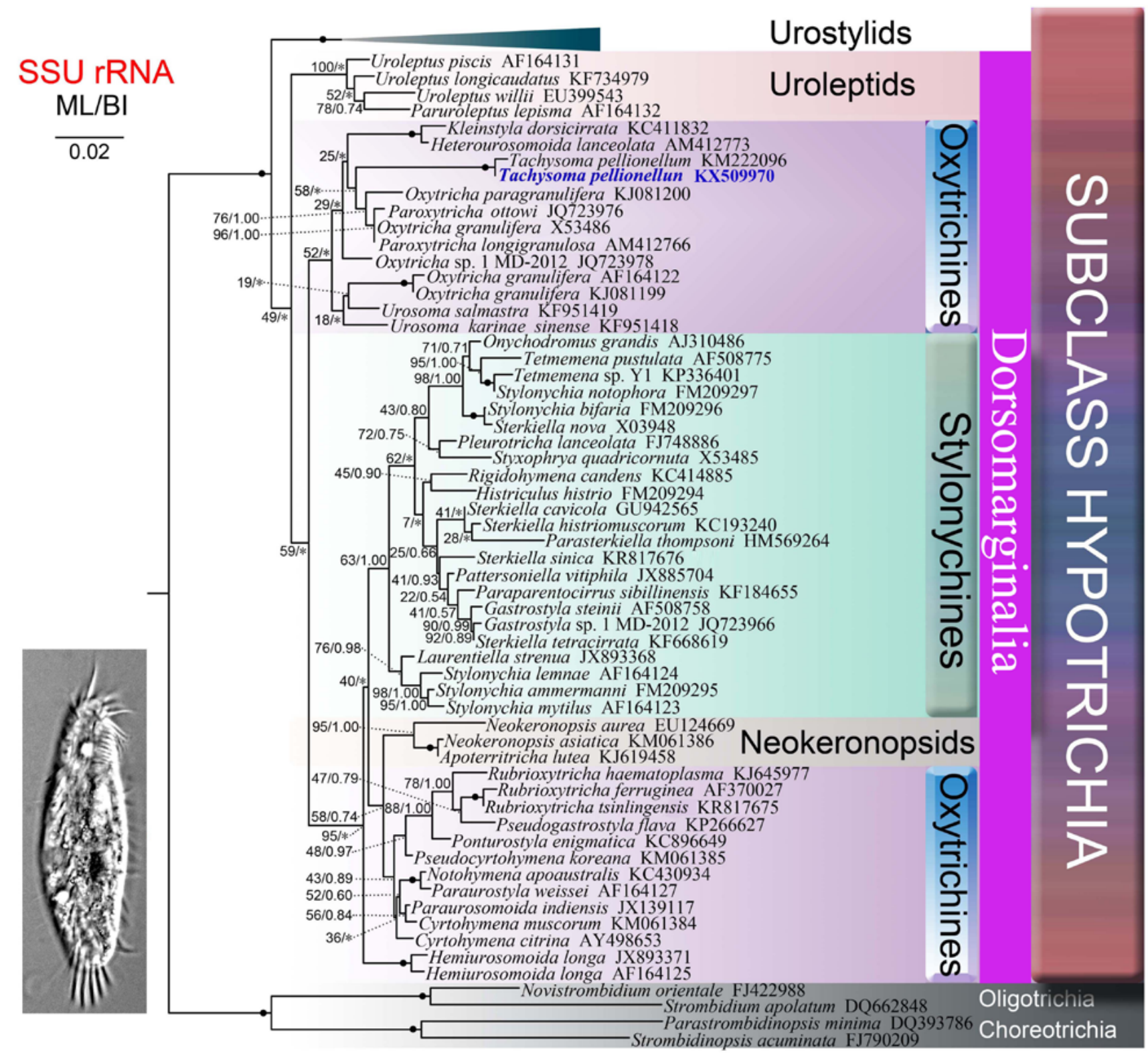

Fig. 7. Maximum likelihood (ML) phylogenetic tree based on the small subunit rRNA (SSU rRNA) gene sequences. Numbers at the nodes represent the bootstrap values of ML analyses and posterior probability of BI analyses. Fully supported $(100 \% / 1.00)$ branches are marked with solid circles. Asterisk (*) represents support values less than 50\% and the disagreement between BI and the reference ML tree. The scale bar corresponds to two substitutions per 100 nucleotide positions. The newly sequenced species in the present study is shown in bold.

tion of the species within the subfamily Oxytrichinae is far from settled. In the present ML tree, Tachysoma clusters with four species of Oxytricha but with weak support. Morphologically, T. pellionellum differs from Oxytricha in the absence (vs. presence) of caudal cirri and development of the dorsal pattern (Berger 1999). However, Tachysoma also has the ventral cirral pattern, dorsomarginal kineties and flexible body of Oxytricha, suggesting a close relationship between the two genera.
Owing to limited taxon sampling in the molecular tree (less than $50 \%$ of oxytrichid species are available), we cannot infer evolutionary relationships within this complex group with confidence. Furthermore, morphogenetic data also are lacking for many oxytrichid genera. Perhaps a final could be proposed that Tachysoma is an artificial assemblage mostly united by the lack of caudal cirri, but with different ventral and dorsal morphogenetic patterns. As more data become available on 
species primarily assigned to Tachysoma, a refinement of the diagnosis of the genus also would be desirable.

Acknowledgements. This work was supported by the National Natural Science Foundation of China (project numbers: 31372148, 31401963, 31430077); The Young Teachers' Promotion Program at Northwest Normal University (NWNU-LKQN-16-11) and the authors extend their sincere appreciation to the Deanship of Scientific Reserarch at King Saud University for funding this work through Research Group (RGP-242); and the China Scholarship Council, which funded an extended visit by the principal author to North Carolina Central University, Durhum, NC, USA. We are very grateful to the reviewer and associate editor for their valuable suggestions and comments.

\section{REFERENCES}

Berger H. (1999) Monograph of the Oxytrichidae (Ciliophora, Hypotrichia). Monogr. Biol. 78: 1-1080

Berger H. (2006) Monograph of the Urostyloidea (Ciliophora, Hypotricha). Monogr. Biol. 85: 1-1304

Berger H. (2008) Monograph of the Amphisiellidae and Trachelostylidae (Ciliophora, Hypotricha). Monogr. Biol. 88: 1-737

Berger H. (2011) Monograph of the Gonostomatidae and Kahliellidae (Ciliophora, Hypotricha). Monogr. Biol. 90: 1-741

Bharti D., Kumar S., Terza, A. L. (2016) Rigidosticha italiensis n. gen., n. sp. (Ciliophora, Spirotricha), novel large hypotrich ciliate from the soil of Lombardia, Italy. Eur. J. Protistol. 56: $112-118$

Bharti D., Kumar S., Terza A. L. (2017) Description and molecular phylogeny of a novel hypotrich ciliate from the soil of Marche Region, Italy; including notes on the MOSYSS project. J. Eukaryot. Microbiol. J. Eukaryot. Microbiol. 64: 678-690

Chen L., Zhao X., Shao C., Miao M., Clamp J. C. (2017) Morphology and phylogeny of two new ciliates Sterkiella sinica sp. nov. and Rubrioxytricha tsinlingensis sp. nov. (Protozoa, Ciliophora, Hypotrichia) from north-west China. Syst. Biodivers. 15: 131142

Foissner W. (2016) Terrestrial and semiterrestrial ciliates (Protozoa, Ciliophora) from Venezuela and Galápagos. Denisia 35: 1-912

Foissner W., Agatha S., Berger H. (2002) Soil ciliates (Protozoa, Ciliophora) from Namibia (Southwest Africa), with emphasis on two contrasting environments, the Etosha region and the Namib Desert. Part I. Text and line drawings. Part II: Photographs. Denisia 5: 1-1459

Gao F., Warren A., Zhang Q., Gong J., Miao M., Sun P., Xu D., Huang J., Yi Z., Song W. (2016). The all-data-based evolutionary hypothesis of ciliated protists with a revised classification of classificationof the phylum Ciliophora (Eukaryota, Alveolata). Sci. Rep. 6, 24874

Hall T. A. (1999) BioEdit: a user-friendly biological sequence alignment editor and analysis program for Windows 95/98/NT. Nucleic Acids Symp. Ser. 41: 95-98

Hemberger H. (1982) Revision der Ordnung Hypotrichida Stein (Ciliophora, Protozoa) an Hand von Protargolpräparaten und Morphogenesedarstellungen. PhD Thesis, University of Bonn, Germany

Huang J., Luo X., Bourland W. A., Gao F., Gao S. (2016) Multigene-based phylogeny of the ciliate families Amphisiellidae and Trachelostylidae (Protozoa: Ciliophora: Hypotrichia). Mol. Phylogenet. Evol. 101: 101-110
Kumar S., Bharti D., Quintela-Alonso P., Shin M. K., Terza A. L. (2016) Fine-tune investigations on three stylonychid (Ciliophora, Hypotricha) ciliates. Eur. J. Protistol. 56: 200-218

Kumar S., Foissner W. (2017) Morphology and ontogenesis of Stylonychia (Metastylonychia) nodulinucleata nov. subgen. (Ciliophora, Hypotricha) from Australia. Eur. J. Protistol. 57: 61-72

Li F., Lyu Z., Li Y., Fan X., Al-Farraj S. A., Shao C., Berger H. (2017) Morphology, morphogenesis, and molecular phylogeny of Uroleptus (Caudiholosticha) stueberi (Foissner, 1987) comb. nov. (Ciliophora, Hypotricha), and reclassification of the remaining Caudiholosticha species. Eur. J. Protistol. 59: 82-98

Li F., Xing Y., Li J., Al-Rasheid K. A. S., He S., Shao C. (2013) Morphology, morphogenesis and small subunit rRNA gene sequence of a soil hypotrichous ciliate, Perisincirra paucicirrata (Ciliophora, Kahliellidae), from the shoreline of the Yellow River, North China. J. Eukaryot. Microbiol. 60: 247-256

Lu X. T., Huang J., Shao C., Al-Farraj S. A., Gao S. (2017) Morphology and morphogenesis of a novel saline soil hypotrichous ciliate, Gonostomum sinicum nov. spec. (Ciliophora, Hypotrichia, Gonostomatidae), including a report on the small subunit rDNA sequence. J. Eukaryot. Microbiol. 64: 32-646

Luo X. T., Gao F., Yi Z., Pan Y., Al-Farraj S. A., Warren A. (2017) Taxonomy and molecular phylogeny of two new brackish hypotrichous ciliates, with the establishment of a new genus (Ciliophora, Spirotrichea). Zool. J. Linn. Soc. 179: 475-491

Medlin L., Elwood H. J., Stickel S., Sogin M. L. (1988) The characterization of enzymatically amplified eukaryotic 16S-like rRNA-coding regions. Gene 71: 491-499

Müller O. F. (1773) Vermium terrestrium et fluviatilium, seu animalium infusorium, helminthicorum et testaceorum, non marinorum, succincta historia. Havniae and Lipsiae.

Nylander J. A. A. (2004) MrModeltest, version 2.2. Evolutionary biology centre, Uppsala University, Uppsala

Page R. D. M. (1996) TREEVIEW: an application to display phylogenetic trees on personal computers. Comput. Appl. Biosci. 12: $357-358$

Park M. H., Jung J. H., Min G. S., Kim S. (2017a) Pseudonotohymena antarctica $\mathrm{n}$. g., n. sp. (Ciliophora, Hypotricha), a new species from Antarctic soil. J. Eukaryot. Microbiol. 64: 447-456

Park M. H., Moon J. H., Kim K. N., Jung J. H. (2017b) Morphology, morphogenesis, and molecular phylogeny of Pleurotricha oligocirrata nov. spec. (Ciliophora: Spirotrichea: Stylonychinae). Eur. J. Protistol. 59: 114-123

Ronquist F., Huelsenbeck J. P. (2003) MrBAYES 3: Bayesian phylogenetic inference under mixed models. Bioinformatics 19: $1572-1574$

Schmidt S. L., Bernhard D., Schlegel M., Foissner W. (2007) Phylogeny of the Stichotrichia (Ciliophora; Spirotrichea) reconstructed with nuclear small subunit rRNA gene sequences: discrepancies and accordances with morphological data. J. Eukaryot. Microbiol. 54: 201-209

Shao C., Gao S., Hu X., Al-Rasheid K. A., Warren A. (2011) Ontogenesis and molecular phylogeny of a new marine urostylid ciliate, Anteholosticha petzi n. sp. (Ciliophora, Urostylida). J. Eukaryot. Microbiol. 58: 254-265

Shao C., Hu X., Warren A., Al-Rasheid K. A. S., Al-Quraishy S. A., Song W. (2007) Morphogenesis in the marine spirotrichous ciliate Apokeronopsis crassa (Claparède \& Lachmann, 1858) n. comb. (Ciliophora: Stichotrichia), with the establishment of a new genus, Apokeronopsis n. g., and redefinition of the genus Thigmokeronopsis. J. Eukaryot. Microbiol. 54: 392-401 
Shao C., Lu X., Ma H. (2015) General overview of the typical 18 frontal-ventral-transverse cirri Oxytrichidae $s . l$. genera (Ciliophora, Hypotrichia). J. Ocean Univ. China. 14: 522-532

Shao C., Pan X., Jiang J., Ma H., Al-Rasheid K. A. S., Warren A., Lin X. (2013) A redescription of the oxytrichid Tetmemena pustulata (Müller, 1786) Eigner, 1999 and notes on morphogenesis in the marine urostylid Metaurostylopsis salina Lei et al., 2005 (Ciliophora, Hypotrichia). Eur. J. Protistol. 49: 272-282

Shao C., Song W., Al-Rasheid K. A. S., Berger H. (2012) Redefinition and reassignment of the 18-cirri genera Hemigastrostyla, Oxytricha, Urosomoida, and Actinotricha (Ciliophora, Hypotricha), and description of one new genus and two new species. Acta Protozool. 50: 263-287

Song W., Warren A., Hu X. (2009) Free-living ciliates in the Bohai and Yellow Seas, China. Science Press, Beijing

Stokes A. C. (1887) Some new hypotrichous infusoria from American fresh waters. Ann. Mag. nat. Hist., Serie 5 20: 104-114, Plate III

Tamura K., Dudley J., Nei M., Kumar S. (2007) MEGA4: molecular evolutionary genetics analysis (MEGA) software Ver. 4.0. Mol. Biol. Evol. 24: 1596-1599

Tchang T., Pang Y., Gu F. (1984) Evolution of nuclear apparatus and ciliatures of Tachysoma pellionella during asexual reproducing cycle. Zool. Res. 5: 189-200
Wallengren H. (1900) Zur Kenntnis der vergleichenden Morphologie der hypotrichen Infusorien. Bih. K. Svenska Vetensk Akad. Handl. 26: 1-31

Wang J., Lyu Z., Warren A., Wang F., Shao C. (2016) Morphology, ontogeny and molecular phylogeny of a novel saline soil ciliate, Urosomoida paragiliformis n. sp. (Ciliophora, Hypotrichia). Eur. J. Protistol. 56: 79-89

Wang J., Li L. F., Warren A., Shao C. (2017) Morphogenesis and molecular phylogeny of the soil ciliate Rigidohymena quadrinucleata (Dragesco and Njine, 1971) Berger, 2011 (Ciliophora, Hypotricha, Oxytrichidae). Eur. J. Protistol. 60: 1-12

Wilbert N. (1975) Eine verbesserte Technik der Protargolimprägnation für Ciliaten. Mikrokosmos 64: 171-179

Zhao X., Gao S., Fan Y., Strueder-Kypke M., Huang J. (2015) Phylogenetic framework of the systematically confused Anteholosticha-Holosticha complex (Ciliophora, Hypotrichia) based on multigene analysis. Mol. Phylogenet. Evol. 91: 238-247

Received on $15^{\text {th }}$ May, 2017; revised on $27^{\text {th }}$ November, 2017; accepted on $27^{\text {th }}$ November, 2017 